\title{
Biodiversity of the Symbiotic Bacteria Associated with Toxic Marine Dinoflagellate Alexandrium tamarense
}

\author{
Xiaoling Zhang1, Xiaoqing Tian', Liyan Ma1, Bing Feng1, Qiaohong Liu1, Lidong Yuan', \\ Chengqi Fan', Hongliang Huang1, Qiao Yang1,2* \\ ${ }^{1}$ Key Laboratory of East China Sea \& Oceanic Fishery Resources Exploitation and Utilization, Ministry of \\ Agriculture, East China Sea Fisheries Research Institute of Chinese Academy of Fishery Sciences, Shanghai, \\ China \\ ${ }^{2}$ SOA Key Laboratory for Polar Science, Polar Research Institute of China, Shanghai, China \\ Email: ${ }^{*}$ cctcc2004@whu.edu.cn
}

Received May 2015

\section{Abstract}

Paralytic shellfish poisoning (PSP) toxins are potent neurotoxins mainly produced by dinoflagellates and being concentrated in bivalves through food web transfer. Increasing number of findings of toxin-producing bacteria in the cells of dinoflagellate such as Alexandriumtamarense supports the hypothesis of the bacterial origin of PSP toxins. Evidence that there are specific symbiosis bacterial taxa associated with the phytoplankton indicates the presence of specific selective mechanisms between them, and implies that the symbiosis bacteria have some vital function to the benefit of the dinoflagellates. Studies on the role of toxin-producing symbiosis bacteria in the marine ecosystem are considered to be becoming more important. Although toxigenic bacteria could be isolated from toxic dinoflagellates, it was not clearly proven whether the isolated bacterial strains based on culture-dependent manner and the corresponding intracellular bacteria were the same because of microbial unculturability. This paper aims to demonstrate the biodiversity of the symbiotic bacteria associated with toxic dinoflagellate $A$. tamarense using the culture-independent high-throughput pyrosequencing method, as well as the phylogenetic analysis based on $16 \mathrm{~S}$ rDNA sequences of the symbiotic cultivable bacteria strains isolated from toxic Alexander tamarense.

\section{Keywords}

Symbiotic Bacteria, Alexandrium tamarense, Paralytic Shellfish Poisoning, Biodiversity

\section{Introduction}

Paralytic shellfish poisoning (PSP) toxins are potent neurotoxins comprising of saxitoxin (STX) and over fifty

\footnotetext{
"Corresponding author.
}

How to cite this paper: Zhang, X.L., Tian, X.Q., Ma, L.Y., Feng, B., Liu, Q.H., Yuan, L.D., Fan, C.Q., Huang, H.L. and Yang, Q. (2015) Biodiversity of the Symbiotic Bacteria Associated with Toxic Marine Dinoflagellate Alexandrium tamarense. Journal of Biosciences and Medicines, 3, 23-28. http://dx.doi.org/10.4236/jbm.2015.36004 
other chemically related analogs based on a tetrahydropurine skeleton and varied in their toxicity [1]. PSTs interfere with the nerve conductance by blocking the voltage-gated sodium channels on excitable cells, and leading to severe neurological symptoms and in some cases death [2]. These toxins are mainly produced by marine dinoflagellates, in particular, Alexandrium spp., Pyrodinum bahamense var. compressum and Gymnodinium catenatum [3], but have also been found to be produced by freshwater cyanobacteria such as Aphanizomenon flos-aquae, Anabaena circinalis and Lyngbya wollei [4]. A report of production of PSTs by the calcareous Rhodophyte Jania sp., is also gaining support [5]. Shellfish feeding on these algal species can accumulate the toxins without exhibiting adverse effects themselves. Thus, the dinoflagellate toxins have been considered as being concentrated in bivalves through food web transfer [4]. This finding that various subclones obtained from a single clone of A. tamarense have large difference in their toxicity, strongly suggests that toxin production is not a hereditary characteristic [6]. Currently PSP toxins have been also detected in the symbiosis bacteria isolated from toxin-producing dinoflagellates [7]-[10]. The theory of a bacterial origin of PST was first suggested by Silva in 1979, and the first reported PST-producing intracellular bacterium marine Moraxella sp. (PTB-1), was isolated from Alexandrium tamarense and bacteria were observed within the dinoflagellate nucleus [11]. The subsequent increasing number of finding of toxin-producing bacteria in the cells of dinoflagellate supports Silva's hypothesis [11]. There is also increasing evidence that there are specific symbiosis bacterial taxa associated with phytoplankton, indicating the presence of specific selective mechanisms, and implying that the symbiosis bacteria have some function to the benefit of the alga, and these interactions could be the product of co-evolution between bacteria and algae over millions of years [12]. Studies on the role of toxin-producing symbiosis bacteria in the marine ecosystem are considered to be becoming more important.

Increasing number of studies have reported the direct observation of intracellular bacteria in toxic species of dinoflagellates, although the bacterial numbers were generally few and such bacteria were not always discernible even with cells of the same algal culture. Although toxigenic bacteria could be isolated from toxic dinoflagellates, it was not clearly proven whether the isolated bacterial strains and the corresponding intracellular bacteria were the same because of marine microbial cultivability. Currently culture-independent high-throughput pyrosequencing analysis is able to provide a thorough description of microbiota community in environmental samples, which also helps to reveal their potential function [13] [14]. This paper aims to demonstrate the biodiversity of the symbiotic bacteria associated with toxic dinoflagellate Alexandrium tamarense using pyrosequencing method, and to discuss the possible interaction of bacteria with the host dinoflagellate.

\section{Materials and Method}

\subsection{Samples Collection and Culture}

The dinoflagellate Alexandrium tamarense was collected and kindly provided by Prof. Hung-Non Chou in Institute of Fisheries Science, National Taiwan University. An axenic culture of Alexandrium tamarense was cultured in $\mathrm{f} / 2$ medium. Cultures were kept at $28^{\circ} \mathrm{C}$ and a $12 \mathrm{~h}$ light:12 h dark cycle with the light intensity of ca. 200 umol photons $\mathrm{m}^{-2} \cdot \mathrm{S}^{-1}$.

\subsection{Isolation of the Cultivable BACTERIAL Strains}

Cultivable bacteria were isolated and maintained on a Zobell 2216E prepared with aged filtered natural seawater, supplemented with GSe trace elements and vitamins were used as necessary [15]. Bacterial isolation was performed by harvesting $1 \mathrm{ml}$ of a late-logarithmic phase A. tamarense culture by brief centrifugation (12 $000 \mathrm{~g}$ for $20 \mathrm{~s})$. The spent medium was removed and the algal cell pellet resuspended in $100 \mu \mathrm{L}$ of sterile seawater and vortexed. The cell suspension was diluted 10 -fold and $100 \mu \mathrm{L}$ of each dilution spread onto 2216E agar plates and incubated in the dark at $25^{\circ} \mathrm{C}$ for 3 - 6 days. Bacterial colonies with distinct colony morphology were picked. Bacterial isolates were grown in 2216 broth, glycerol was added $(25 \% \mathrm{v} / \mathrm{v})$, and the cells were stored at $-80^{\circ} \mathrm{C}$.

\subsection{DNA Extraction and PCR Amplification}

Genomic DNA of the sample was extracted using Wizard ${ }^{\circledR}$ DNA Kit (Promega, Madison, USA) following the manufacturer's instruction. The quality of extracted DNA was checked by $0.8 \%$ agarose gel electrophoresis and spectrophotometry (optical density at $260 \mathrm{~nm} / 280 \mathrm{~nm}$ ratio). The V3-V4 region of bacterial 16S rRNA were amplified by PCR for high-throughput pyrosequencing. The 16S rRNA gene V3-V4 region of bacteria was amplified using the universal primers of the forward 338F (5'-ACTCCTACGGGAGGCAGCA-3') and the reverse 
806R (5'-GGACTACHVGGGTWTCTAAT-3'). PCR amplifications of the 16S rRNA V3-V4 region were performed. PCR program was as follows: $95^{\circ} \mathrm{C}$ for $3 \mathrm{~min} ; 27$ cycles of $95^{\circ} \mathrm{C}$ for $30 \mathrm{~s}, 55^{\circ} \mathrm{C}$ for $30 \mathrm{~s}$, and $72^{\circ} \mathrm{C}$ for 45 $\mathrm{s}$ with a final extension of $72^{\circ} \mathrm{C}$ for $10 \mathrm{~min}$. The amplicon mixture was applied to the HiSeq $2500 \mathrm{MiSeq}$ Genome Sequencer (Illumina, San Diego, CA, USA).

\subsection{High-Throughput Sequencing}

Extraction of high-quality DNA was performed and the raw sequences were selected and the low-quality sequences were removed. Alignment of the extracted high-quality sequences were performed using PyNAST and UCLUST. The unique sequence set was classified into operational taxonomic units (OTUs) under the threshold of $97 \%$ identity using UCLUST. Chimera Slayer was applied to remove the potential chimeric sequences in the representative set of OTUs. Alpha-diversity is used to analyze the microbial diversity. The index for the community richness includes Chao-the Chao1 estimator (http://www.mothur.org/wiki/Chao) and Ace-the ACE estimator (http://www.mothur.org/wiki/Ace). The index for the community diversity includes the Shannon index (http://www.mothur.org/wiki/Shannon) and the Simpson index (http://www.mothur.org/wiki/Simpson). Sequencing depth index is Coverage - the Good's coverage (http://www.mothur.org/wiki/Coverage). MOTHUR (version v.1.30.1, http://www.mothur.org/wiki/Schloss_SOP\#Alpha_diversity) is used for data analysis.

\section{Results}

\subsection{Bacterial Sequence Abundance}

As shown in Table 1, a total of 102,131 of bacterial V3-V4 16S rRNA raw sequence reads were generated from the samples. The number of unique and classifiable representative OTU sequences for bacteria was 98 . Based on homologous sequence alignment method and clustering with information extracted from the RDP and BLAST databases, the lowest level of taxonomy of the identified OTUs was determined. The rarefaction and Shannon diversity curves for the samples reached the saturation phase (Figure 1), indicating the majority of bacterial phylotypes of the sample had already been covered. As shown in Table 1, the Shannon index, Simpson diversity index, Chao1 and observed species of each sample were used to evaluate the species richness and diversity indicates large distinction of species richness and diversity of the bacterial community within the sample.

\subsection{Bacterial Diversity Based on Pyrosequencing Analysis}

Eight bacterial phyla were identified in the Alexander tamarense culture sample in this study (Figure 2), namely
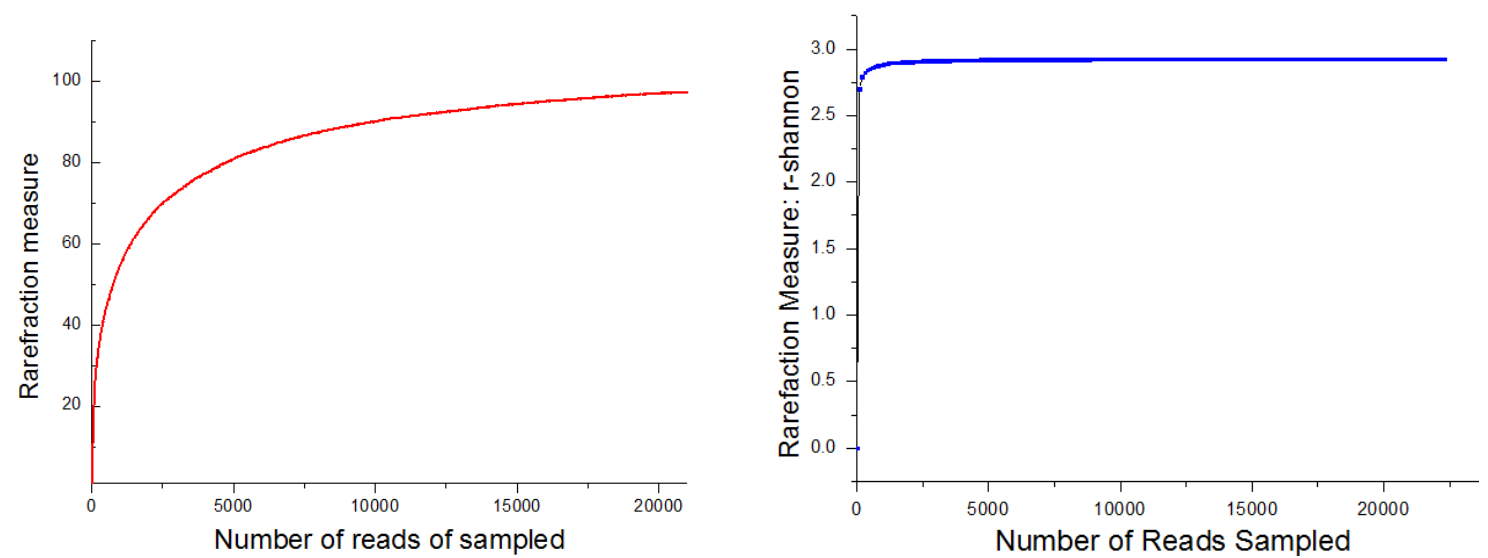

Figure 1. The Shannon diversity curve of the samples investigated in this study.

Table 1. Statistics data of the obtained sequences for V3-V4 region of bacteria 16S rRNA gene using the 338F-806R primer.

\begin{tabular}{cccccc}
\hline OTU & coverage & Ace index & Chao1 index & Shannon index & Simpson index \\
\hline 98 & 0.999641 & 102 & 102 & 2.93 & 0.09 \\
\hline
\end{tabular}


Proteobacteria, Bacteroidetes, Firmicutes, Planctomycetes, Actinobacteria, Verrucomicrobia, Gemmatimonadetes and Cyanobacteria. The predominant phylum was Proteobacteria, accounting for $59.18 \%$ of the total bacterial sequences. Bacteroidetes, Planctomycetes, Actinobacteria, and Firmicutes were the subdominant phyla, which contributed to $14.28 \%, 13.26 \%, 6.12 \%$ and $4.08 \%$ of the total bacterial sequences, respectively. Minor phyla, including Verrucomicrobia, Gemmatimonadetes and Cyanobacteria, together contributed to $3.06 \%$ of the total bacterial sequences.

The major bacterial genera belonged to Proteobacteria including Rhodobacteraceae, Hyphomonadaceae, Phycisphaera, Dinoroseobacter, of $25.79 \%, 13.05 \%, 12.43 \%$ and $11.1 \%$, respectively. The most abundant genus, Rhodobactgeraceae, was comprised of 10 different types of OTUs (Figure 2). Based on the phylogenetic tree, there is still 5.29\% unknown data could be further assigned to the potential new species.

\subsection{Bacterial Diversity Using Culture-Independent Phylogenetic Analysis}

In order to develop the furthering interaction study of symbiotic bacteria with the host dinoflagellate, the culture-independent isolation of the cultivable symbiotic bacteria strains from toxic Alexander tamarense and the bacterial diversity based on phylogenetic analysis of the 16S rDNA sequences of the isolated bacteria strains were performed. Total 12 bacterial strains were isolated from the Zobell 2216 marine agar. Based on the result as shown in Figure 3 and Figure 4, the obtained bacterial diversity is in well consistent with the phylogenetic

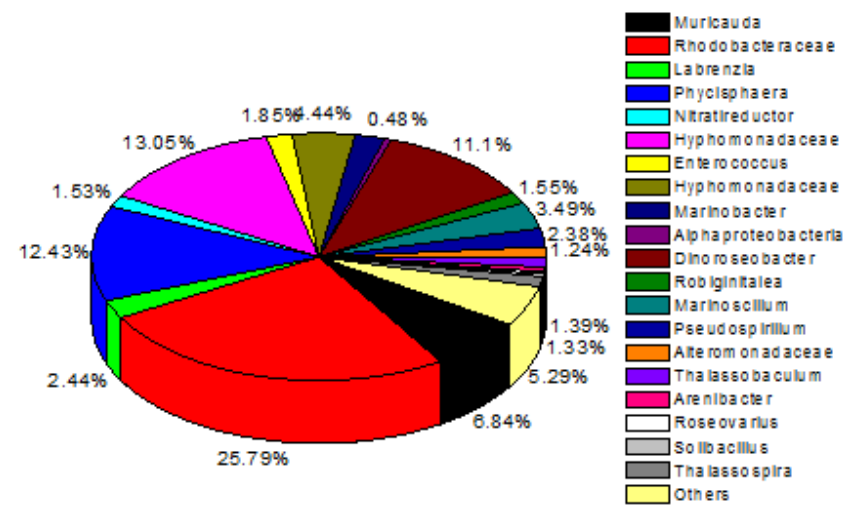

Figure 2. Microbial species biodiversity analysis of the symbiotic bacteria of Alexander tamarense culture.

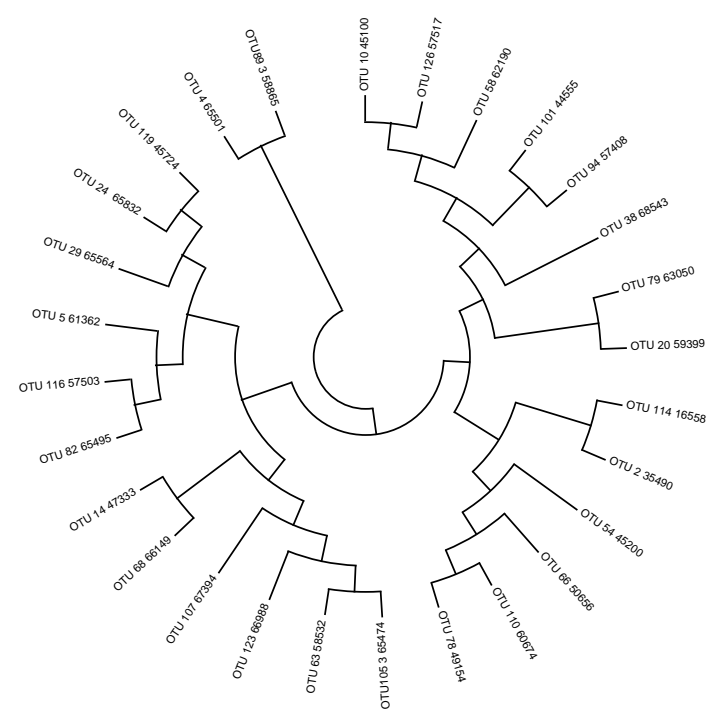

Figure 3. Phylogenetic tree based on OTU sequences of the symbiotic bacteria strains from toxic Alexander tamarense. 


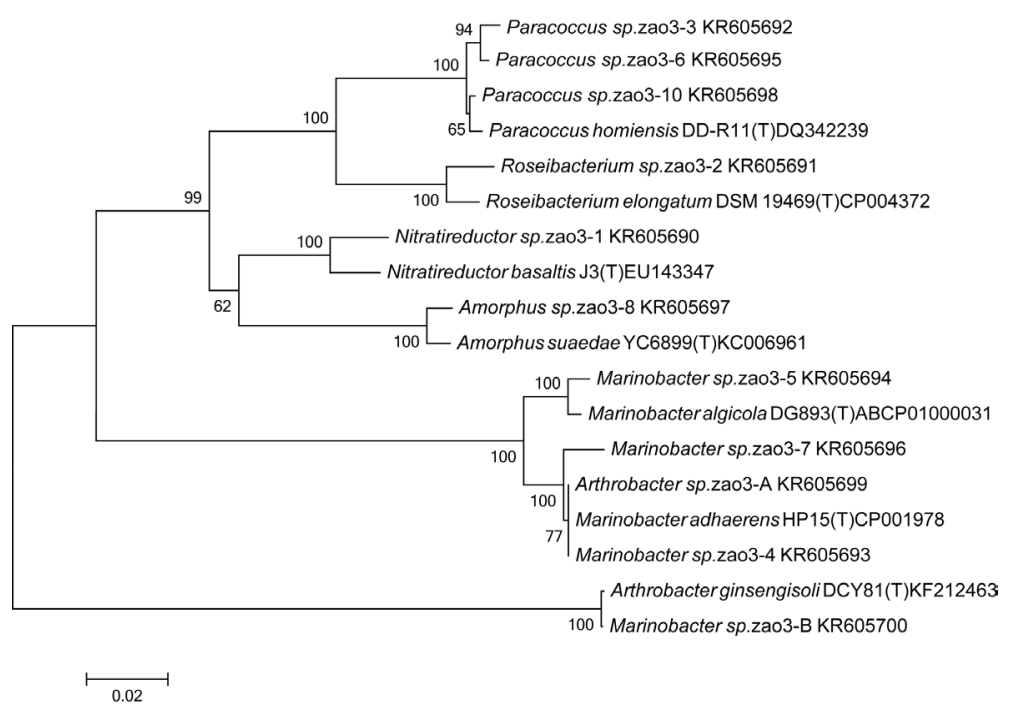

Figure 4. Phylogenetic tree based on $16 \mathrm{~S}$ rDNA sequences of the symbiotic cultivable bacteria strains isolated from toxic Alexander tamarense.

analysis using pyrosequencing anslysis.

\section{Conclusion}

Currently culture-independent high-throughput pyrosequencing analysis is able to provide a thorough description of microbial community in environmental samples, which also helps reveal their potential function. This study demonstrated the biodiversity of the symbiotic bacteria associated with toxic dinoflagellate $A$. tamarense using the culture-independent high-throughput pyrosequencing method, as well as the phylogenetic analysis based on 16S rDNA sequences of the symbiotic cultivable bacteria strains isolated from toxic Alexander tamarense. The obtained results showed that species richness and diversity of the bacterial community existed within the sample. It will be valuable to develop the interaction study of symbiotic bacteria with the host dinoflagellate in the near future.

\section{Acknowledgements}

This study was financially supported from special fund for National Non-profit Institutes (East China Sea Fisheries Research Institute) (2012T08), National Natural Science Foundation of China (41206093) and the Opening Project (KP201406) of SOA Key Laboratory for Polar Science, Polar Research Institute of China.

\section{References}

[1] Thottumkara, A.P., Parsons, W.H. and Du Bois, J. (2014) Saxitoxin. Angewandte Chemie International Edition, 53, 5760-5784. http://dx.doi.org/10.1002/anie.201308235

[2] Zhang F., Xu, X., Li, T. and Liu, Z. (2013) Shellfish Toxins Targeting Voltage-Gated Sodium Channels. Mar Drugs, 11, 4698-4723. http://dx.doi.org/10.3390/md11124698

[3] Orr, R.J., Stüken, A., Murray, S.A. and Jakobsen, K.S. (2013) Evolution and Distribution of Saxitoxin Biosynthesis in Dinoflagellates. Marine Drugs, 11, 2814-2828. http://dx.doi.org/10.3390/md11082814

[4] Etheridge, S.M. (2010) Paralytic Shellfish Poisoning: Seafood Safety and Human Health Perspectives. Toxicon, 56, 108-122. http://dx.doi.org/10.1016/j.toxicon.2009.12.013

[5] Cembella, A.D. (1998) Ecophysiology and Metabolism of Paralytic Shellfish Toxins in Marine Microalgae. In: Anderson, O.M., Cembella, A.D. and Hallegraeff, G.M., Eds., Physiological Ecology of Harmful Algal Blooms, NATO ASI Series Vol. G41, Springer-Verlag, Berlin, Heidelberg, 381-403.

[6] Kodama, M. (2010) Paralytic Shellfish Poisoning Toxins: Biochemistry and Origin. Terrapub, Orono.

[7] Gallacher, S. and Smith, E.A. (1999) Bacteria and Paralytic Shellfish Toxins. Protist, 150, 245-255. http://dx.doi.org/10.1016/S1434-4610(99)70027-1 
[8] Gallacher, S., Flynn, K.J., Franco, J.M., Brueggemann, E.E. and Hines, H.B. (1997) Evidence for Production of Paralytic Shellfish Toxins by Bacteria Associated with Alexandrium spp. (Dinophyta) in Culture. Applied and Environmental Microbiology, 63, 239-245.

[9] Green, D.H., Llewellyn, L.E., Negri, A.P., Blackburn, S.I. and Bolch, C.J. (2004) Phylogenetic and Functional Diversity of the Cultivable Bacterial Community Associated with the Paralytic Shellfish Poisoning Dinoflagellate Gymnodinium catenatum. FEMS Microbiology Ecology, 47, 345-357. http://dx.doi.org/10.1016/S0168-6496(03)00298-8

[10] Dantzer, W.R. and Levin, R.E. (1997) Bacterial Influence on the Production of Paralytic Shellfish Toxins by Dinoflagellated Algae. Journal of Applied Microbiology, 83, 464-469. http://dx.doi.org/10.1046/j.1365-2672.1997.00246.x

[11] Kodama, M., Ogata, T., Sakamoto, S., Sato, S., Honda, T. and Miwatani, T. (1990) Production of Paralytic Shellfish Toxins by a Bacterium Moraxella sp. Isolated from Protogonyaulax tamarensis. Toxicon, 28, 707-714. http://dx.doi.org/10.1016/0041-0101(90)90259-A

[12] Kodama, M., Sakamoto, S. and Koike, K. (1996) Symbiosis of Bacteria in Alexandrium tamarense. Harmful and Toxic Algal Bloom. Intergovernmental Oceanographic Commission of UNESCO, Paris, 351-354.

[13] McCann, J.C., Wickersham, T.A. and Loor, J.J. (2014) High-Throughput Methods Redefine the Rumen Microbiome and Its Relationship with Nutrition and Metabolism. Bioinformatics and Biology Insights, 8, 109. http://dx.doi.org/10.4137/BBI.S15389

[14] Andersson, A. F., Lindberg, M., Jakobsson, H., Bäckhed, F., Nyrén, P. and Engstrand, L. (2008) Comparative Analysis of Human Gut Microbiota by Barcoded Pyrosequencing. PloS ONE, 3, e2836. http://dx.doi.org/10.1371/journal.pone.0002836

[15] Su, J.Q., Yang, X.R., Zheng, T.L., Tian, Y., Jiao, N.Z., Cai, L.Z. and Hong, H.S. (2007) Isolation and Characterization of a Marine Algicidal Bacterium against the Toxic Dinoflagellate Alexandrium tamarense. Harmful Algae, 6, 799-810. http://dx.doi.org/10.1016/j.hal.2007.04.004 